\section{Marine Geology}

Volume 229, Issues 1-2, 30 May 2006, Pages 1-14

http://dx.doi.org/10.1016/j.margeo.2006.02.004

(c) 2006 Elsevier B.V. All rights reserved
Archimer, archive institutionnelle de l'Ifremer http://www.ifremer.fr/docelec/

\title{
Estimating mud expulsion rates from temperature measurements on Håkon Mosby Mud Volcano, SW Barents Sea
}

\author{
N. Kaul ${ }^{\mathrm{a},{ }^{\star}}$, J.-P. Foucher ${ }^{\mathrm{b}}$ and M. Heesemann ${ }^{\mathrm{a}}$
}

\author{
aUniversität Bremen, Geowissenschaften, Klagenfurter Strasse, 28359 Bremen, Germany \\ ${ }^{\mathrm{b}}$ IFREMER, BP70, 29280 Plouzane, France \\ *: Corresponding author : Universität Bremen, FB5, PO box 330440, 28334 Bremen, Germany. Tel.: +49 421218 \\ 7162; fax: +49 421218 7163; email : nkaul@uni-bremen.de
}

\begin{abstract}
:
The Håkon Mosby Mud Volcano (HMMV), located on the Norwegian-Barents-Svalbard continental margin in $1250 \mathrm{~m}$ water depth, has been identified and described as a structure caused by upward transport of mud, pore water and gas [e.g. Eldholm, O., Sundvor, E., Vogt, P.R., Hjelstuen, B.O., Crane, K., Nilsen, A.K., Gladczenko, T.P., 1999. SW Barents Sea continental margin heat flow and Håkon Mosby Volcano. Geo-Marine Letters 19, 29-37]. During RV Polarstern expedition ARK XIX/3b in 2003, an integrated study took place to investigate the detailed morphology, biology, chemistry and geophysical aspects of HMMV [Klages, M., Thiede, J., Foucher, J.-P., 2004. The Expeditions ARK XIX $3 \mathrm{a}, 3 \mathrm{~b}$ and $3 \mathrm{c}$, Berichte zur Polarforschung, 488.]. In this paper, we describe a detailed survey involving more than 100 temperature gradient measurements in order to reveal the temperature structure of HMMV. Values of apparent heat flow up to $3000 \mathrm{~mW} / \mathrm{m}^{2}$ and absolute temperatures up to $25.8^{\circ} \mathrm{C}$ have been detected. These enormously high heat flux values do not reflect deep-seated thermal gradients but are a result of surface mud flows. The occurrence and abundance of mud flows varies in different areas within the HMMV inner crater. A combination of very shallow, ROV-derived temperature measurements, a large number of intermediate depth temperature gradients and nine deep penetrating gravity corers allows us to reconstruct the history of activity of HMMV. Modeling of the observed temperature gradients indicates vigorous activity with very recent mud flows. Furthermore, the supply of energy and material from the HMMV is estimated to have an annual mass volume of $\mathrm{r} \times 15,000 \mathrm{~m}^{3}$. From the thermal corona of HMMV and the observed horizontal heat flux, it is possible to deduce that the long term temperature of the mud pond is stable at a temperature approximately similar to the recent maximum temperature of $25^{\circ} \mathrm{C}$.
\end{abstract}

Keywords: seafloor hydrothermal system; mud volcano; heat flow; convection; SW Barents Sea 


\section{Introduction}

During the 2003 multi-discipline R/V Polarstern cruise ARK XIX/3b investigations of Håkon Mosby Mud Volcano (HMMV) were carried to better understand the thermal structure of this only $1 \mathrm{~km}$ wide structure. A review of heat flow measurements and thermal field in the Norwegian-Greenland Sea and on HMMV has been given by Eldholm et al. (1999) while the thermal evolution of Svalbard Margin was investigated systematically by Crane et al. (1988) (see figure 1). Data reveal a regional background heat flow of $53-75 \mathrm{~mW} / \mathrm{m}^{2}$ with only slight excursions up to $122 \mathrm{~mW} / \mathrm{m}^{2}$ when crossing the Senja Fracture zone (SFZ). Heat flow values are slightly decreasing from the Lofoten Basin in the West with water depth of $2800 \mathrm{~m}$ to the SW Barents Sea in the East, where water depth is only $500 \mathrm{~m}$. Interpretation of seismic data (Hjelstuen, 1999) shows, that not only water depth becomes shallower but the section of preglacial and glacial sediments on top of oceanic crust increases from $3 \mathrm{~km}$ to about $6 \mathrm{~km}$ at maximum. The HMMV is situated near the maximum sediment thickness within the basin, underlain by $3 \mathrm{~km}$ glacial plus $3.2 \mathrm{~km}$ preglacial sequences. Ties to commercial wells indicate an age of $2.3 \mathrm{Ma}$ for the base of the glacial unit (Fiedler and Faleide, 1996), resulting in an extremely high sedimentation rate of $135 \mathrm{~cm} / 1000 \mathrm{y}$ for the last $2.3 \mathrm{Ma}$. From magnetic anomalies, the age of the underlying oceanic crust is estimated as $33-37 \mathrm{Ma}$ (Hjelstuen, 1999). Calculating a background heat flow according to Parsons \& Sclater (1977) yields a value of app. $80 \mathrm{~mW} / \mathrm{m}^{2}$.

Unusual high heat flow values were detected at HMMV site by measurements from Eldholm (1999), indicating a convective heat transport while optical imagery found features attributed to gas or fluid expulsion (Vogt et al., 1997). Therefore detailed thermal investigations have been planned along with numerous geological work on methane gas and gas hydrate occurrences at HMMV. This structure has been inferred as an active mud volcano due to outflow channels, observed by side scan observations (Vogt et al. 1999). Taking the terminology of Kopf (2002), the structure is more a mud pie (flank slope $<5^{\circ}$ ) rather than a volcano, indicating production of low viscosity mud. Gas hydrates have been recovered during coring (Ginsburg et al., 1999). As a consequence, we expect a thermal field, which is heavily affected by transient effects and mass convection. Under these circumstances it would be misleading to use the term heat flow determinations, as this would require at least a quasi-steadystate situation for a reasonable long time period. We rather refer to temperature measurements and processes they describe. In comparison to this feature the much smaller structure "Mound 11" off the coast of Costa Rica shows an only slightly disturbed temperature field even though the mound is active in terms of gas hydrate generation and $\mathrm{CH}_{4}$ degassing (Schmidt et al., 2005). 


\section{Instrumentation}

Three different tools were used to measure a large number of temperature gradients in the shallow ( $<1 \mathrm{~m}$ ), intermediate $(0-4 \mathrm{~m})$, and "deep" (up to 16 mbsf) sediment depth range. The lateral resolution varied from $50 \mathrm{~m}$ to some hundred meters, depending on the instrument used.

During this cruise it was possible to take advantage of ROV "Victor 6000" for shallow and closely spaced temperature measurements. During several dives shallow sea floor temperature gradients at a spacing of $50 \mathrm{~m}$ could be obtained. A temperature lance with two autonomous data logger of type Micrel THP were used (Géli, 2001). These temperature loggers have a resolution of better than 1 $\mathrm{mK} @ 20^{\circ} \mathrm{C}$ and a capacity of app. 25000 samples with data compression. The housing has a diameter of $28 \mathrm{~mm}$ and is rated at 600 bar. Two of these sensors were mounted at 0.25 and $0.55 \mathrm{~m}$ (sensor position) below the top of the lance, which could be handled by the ROVs manipulator arm. Penetration depth could be controlled very accurately by "Victor 6000" so that we are confident that we get a correct temperature gradient for the uppermost centimetres below the mudline. Figure 2 gives an impression of the instrument and the seafloor conditions.

For the medium depth range between 0.8 and $4 \mathrm{~m}$, a conventional heat flow probe for multipenetration stations was used. The Bremen heat probe is a violin bow instrument of Lister type design and capable of $3.5 \mathrm{~m}$ penetration with a number of 11 sensors, distributed over a length of $3 \mathrm{~m}$ at a spacing of $0.3 \mathrm{~m}$. Furthermore it determines in-situ thermal conductivity at all 11 thermistor positions (Hyndman 1979).

Survey lines across HMMV are planned for detailed investigation, thus distances between points in line are as short as $100 \mathrm{~m}$ while crossing the centre, and $200-300 \mathrm{~m}$ outside. From the very first profile (H0310), we learned that temperature anomalies close to the seafloor are very distinct and limited in extent. Therefore survey lines make up a grid with many crossings near the centre of HMMV. From Eldholm et al. (1999) it is known that heat flow background values of $55-70 \mathrm{~mW} / \mathrm{m}^{2}$ are present at a distance of only some kilometres from HMMV, thus we did not extend our profiles more than $10 \mathrm{~km}$. In total a number of 97 measurements could be achieved out of 98 attempts. Obviously the sea floor conditions are very favourable for instrument penetration down to $4 \mathrm{~m}$. Figure 3 shows the distribution of these measurements overlain over high resolution bathymetry. The bathymetry is a result of a systematic survey by the deep flying "Victor 6000".

To prolong "shallow" temperature measurements into greater depth, a gravity corer was equipped with autonomous temperature probes. Ten instruments of Micrel type were welded onto the core barrel at 0.88 or $1 \mathrm{~m}$ spacing. Six gravity corer stations gave reliable temperature measurements down to a maximum depth of $16 \mathrm{~m}$. Three stations failed due to bended core barrels. We attribute this to rigid layers of gas hydrate some metres below the seafloor which could not be penetrated. The positions of deep reaching temperature profiles are chosen at or close to known thermal anomalies. The accuracy of the positions 
at the seafloor is estimated as $\pm 30 \mathrm{~m}$. The position of the surface vessel is known with DGPS accuracy, the uncertainties are introduced due to the range determination of the tethered instrument or the ROV. However, we are confident that the position uncertainty does not interfere with thermal effects. Thus we are able to combine the different techniques to a temperature gradient from the seafloor up to 16 mbsf. This is an essential approach because none of the methods would give the entire picture in this thermally heterogeneous environment.

\section{Thermal measurements}

A total number of 98 successful temperature gradient determinations could be achieved with the Bremen heat probe and additional 9 profiles with a gravity corer, equipped with thermistors plus two horizontal profiles of shallow temperature measurements with the mini lance, operated with "Victor 6000". All measurements concentrated on the HMMV crater including its moat. Detailed surveys with the mini lance were located at key sites, chosen from previous heat flow investigations or visual inspection by ROV "Victor 6000". Navigation of the ROV is relative to the surface vessel by means of one Posidonia ${ }^{\mathrm{TM}}$ acoustic transponder. True ground positions were accurate within $+/-30 \mathrm{~m}$, deduced from the relocation of known features. Only few sites were positioned outside the crater, up to $10 \mathrm{~km}$, to get a regional reference for temperatures and gradients. Due to a very soft seafloor consistency in the centre of HMMV we have to consider "over-penetration" for the heavy instruments, i. e. penetration is larger than the maximum length of the lance and thus poorly constrained.

3.1 Surface measurements using a mini-lance: A closer look at the data from the Mini-lance shows temperatures of $0^{\circ} \mathrm{C}-+13^{\circ} \mathrm{C}$ at $0.25 \mathrm{mbsf}$ and $+0.1^{\circ} \mathrm{C}-+22^{\circ} \mathrm{C}$ at $0.55 \mathrm{mbsf}$. The maximum resulting temperature gradient within the uppermost half meter of the sediment is as high as $41000 \mathrm{mK} / \mathrm{m}$, assuming a bottom water temperature of $-0.8^{\circ} \mathrm{C}$ (figure 4). This is by far more than can be sustained by basal conductive heat flow as this would lead to unrealistic high sub-seafloor temperatures. This leads to the question: How deep do these high gradients reach?

3.2 Heat flow probe temperature determinations: Usage of the heat flow probe gives information on the temperature distribution down to app. 3.5 mbsf at 92 locations within the crater and the immediate surrounding (max. 2 $\mathrm{km}$ distance from the centre) and 6 at a distance of app. $45 \mathrm{~km}$. One example of one profile crossing HMMV from NW to SE is given in figure 5. The compilation of data points in the vicinity of HMMV is given in figure 6 . The singularity of the temperature distribution becomes evident from the smoothed $x-y-t$ plot.

At a range of $1 \mathrm{~km}$ from the rim of the crater, we find temperatures as low as $0.8^{\circ} \mathrm{C}$ slightly increasing downward with a gradient of app. $55-65 \mathrm{mK} / \mathrm{m}$.

Thermal conductivity determinations, taken by in situ during measurements, give values of $1.0-1.2 \mathrm{~W} / \mathrm{m}^{*} \mathrm{~K}$ increasing downwards, with a mean value of app. $1.1 \mathrm{~W} / \mathrm{m}^{*} \mathrm{~K}$. This results in heat flow values of $60-73 \mathrm{~mW} / \mathrm{m}^{2}$, a heat flow 
which has been found for the region within several hundred kilometres around (Eldholm et al. 1999).

The other extreme end of observations is at a location slightly NW of the geometrical centre of the crater where an almost homogeneous temperature distribution at a temperature of $+25^{\circ} \mathrm{C}$ exists (figure $5 \mathrm{~g}$ ). A closer investigation of this site reveals that the temperature distribution has a clear maximum of $25.8^{\circ} \mathrm{C}$ at $1-2 \mathrm{~m}$ depth, and decreasing temperatures upward $\left(24.7^{\circ} \mathrm{C}\right)$ and downward $\left(24.8^{\circ} \mathrm{C}\right)$. This is the highest temperature encountered during this and all other published surveys of HMMV. The majority of measurements exhibits a more or less linear positive gradient. Values range from app. 60 $\mathrm{mK} / \mathrm{m}$ to $2700 \mathrm{mK} / \mathrm{m}$ next to the centre. Strong indications of convective heat transport within the pore space is attributed to curved gradients. Curvature of gradients is often convex, indicating upward migration of pore water, which can be observed in a few cases (figure $5 \mathrm{a}$ and $\mathrm{b}$ ). Looking at the distribution of temperatures, we find that a huge horizontal gradient exists. Taking values at 3 - $4 \mathrm{~m}$ depth, we find an overall horizontal gradient of $28.2^{\circ} \mathrm{C} / \mathrm{km}$ from a "normal" background gradient to the centre (i.e. H0310P02 - H0310P07, figure $5 \mathrm{~b}-\mathrm{g}$ ). Crossing the moat rim of the crater, we find an enormous temperature difference of $13^{\circ} \mathrm{C}$ over a horizontal distance of $200 \mathrm{~m}$, that is a gradient of $65^{\circ} \mathrm{C} / \mathrm{km}$ (H0310P10 - H0310P11, figure 5j and k). Both, vertical and horizontal gradients give evidence for a very active system which is able to maintain such huge temperature gradients.

3.3 Gravity corers with attached temperature probes: Long gravity corers equipped with temperature probes allowed determination of deep temperature profiles within and outside the crater. Five sites are located near the centre (GC 2, GC 4, GC 6, GC 7 and GC 8) and one site (GC 3) is positioned SE outside the rim (figure 2). Figure $7 \mathrm{a}-\mathrm{f}$ displays the temperaturedepth correlations. GC 3 outside the crater shows a normal positive gradient of app. $79 \mathrm{mK} / \mathrm{m}$ in good agreement with close-by $3 \mathrm{~m}$ deep heat flow stations. At all other sites, gradients are not at all linear but tend to reach a maximum value in an asymptotic manner. A temperature of $23^{\circ} \mathrm{C}$ is never exceeded. However, the asymptotic temperature increase is at its limit in two places (GC 2 and GC 7) but not at sites GC 4, GC 6 and GC 8 suggesting even higher temperatures further below. Nevertheless a temperature above $26^{\circ} \mathrm{C}$ has never been reported from HMMV, neither in greater depth nor in different places.

3.4 Combining results: The combination of all three methods reveals the heterogeneous layering since none of the three methods of temperature measurements gives the whole picture of thermal processes at HMMV.

At the central location, a combination of data is possible as individual positions of measurements are less than $50 \mathrm{~m}$ apart. We combine stations H0310P07 and GC 7 with data from the mini-lance yielding a $9.5 \mathrm{~m}$ long temperature profile with 18 data points. A bulge of high temperatures (figure 8 ) is documented by shallow and medium deep sensors. Decreasing temperatures above 1 mbsf and below 4 mbsf indicate a mud layer thickness of app. $4 \mathrm{~m}$. Temperatures below 5 mbsf depict a positive linear gradient of $0.64^{\circ} \mathrm{C}$ over 3.93 
$\mathrm{m}\left(0.163^{\circ} \mathrm{C} / \mathrm{m}\right)$. This is a relatively low gradient in conjunction with low temperature at $10 \mathrm{~m}$ depth, compared to the other gravity corer profiles. We interpret this as a less vigorous convective cooling below the mud covered area.

\section{Calculation of mud and fluid flow}

From horizontal and vertical temperature distributions we anticipate a model of eruptive mud expulsions from a single channel near the geometrical centre of HMMV. As a temperature-difference of more than $25^{\circ} \mathrm{C}$ to ambient environment is maintained within a considerable area of the crater, we have to suppose a heat supply at a rate, high enough to counteract conductive cooling. This leads to a number of questions: how often are eruptions likely to occur? Can we determine the maximum temperature of a mud flow? Are estimates possible for the history of certain areas, deduced from temperature measurements? FEMLAB® $3.0 \mathrm{a}$ is used for finite-difference method numerical calculations. To start modelling, we hypothesise that warm mud is produced at the centre of HMMV producing distinctive mud flows (figure 9). The thickness (a) of this individual mud layer is estimated from the temperature maximum at penetration H0310P07 (figure $5 \mathrm{~g}$ ) to be $4 \mathrm{~m}$. The expulsion temperature of this mud flow at time $\mathrm{t}=0$ with starting temperature $\mathrm{T}_{0}$ is suggested to be between $26^{\circ} \mathrm{C}$ and $28^{\circ} \mathrm{C}$. Ambient temperature above is $-0.8^{\circ} \mathrm{C}$. The lower boundary condition is a basal heat flow of $170 \mathrm{~mW} / \mathrm{m}^{2}$, deduced from the temperature gradient, found at site GC 2. Figure 8 shows the best fitting result with parameters $T_{0}=26^{\circ} \mathrm{C}$ and a time for temperature equalisation of 2.9 days. Much higher starting temperatures result in inadequate temperature distributions. Simulations with parameter variations within reasonable limits all give ages between 2.5 and 3.5 days for this specific mud flow. Thus we are confident that we were lucky to find a mud flow, younger than three days with a core temperature of $25.8^{\circ} \mathrm{C}$. Taking the above mentioned mud flow as a singular effect, it would take $3 \frac{1}{2}$ months to get into equilibrium (99\%) with its surrounding. The modelling is most sensitive to the uppermost temperature values and least sensitive to the basal heat flow, thus even position uncertainties of GC 2 which contributes the deeper part of the section, is not critical to the modelling result.

A second model hypothesis tries to elucidate what total amount of mud has to be conveyed through the vertical conduit to feed a source of $26^{\circ} \mathrm{C}$ warm mud in a cold environment. We assume a single circular feeder channel of width $D$ (figure 9), rooted at 3000 mbsf. The geometry of this model is derived from seismic data, published by Hjelstuen et al. (1999). Two seismic lines (D2-82 and 7200-77) give evidence, that the conduit of HMMV originates at $2.5-3 \mathrm{~km}$ depth, that is within the $3.1 \mathrm{~km}$ thick glacial unit, sedimented since Pliocene times. Our model starts at this depth as the most probable depth of origin at a temperature $\mathrm{T}(3000 \mathrm{~m})$ of $162^{\circ} \mathrm{C}$, yielding the lower boundary condition. This temperature corresponds to a mean regional heat flow of $65 \mathrm{~mW} / \mathrm{m}^{2}$ at a thermal conductivity of $1.2 \mathrm{~W} / \mathrm{m}^{*} \mathrm{~K}$. The upper boundary condition of the feeder channel is given by the outflow temperature of $26^{\circ} \mathrm{C}$. Densities of mud within the conduit and surrounding material are 1950 and $2000 \mathrm{~kg} / \mathrm{m}^{3}$ resp., specific thermal capacity of mud is taken as $1040 \mathrm{~J} / \mathrm{kg}^{*} \mathrm{~K}$. A number of simulations with varying diameters from $1-1200 \mathrm{~m}$ have been calculated to accomplish the 
thermal boundary conditions at the upper and lower end of the feeder channel. Conduits smaller than $1 \mathrm{~m}$ are difficult to model, since the numerical calculation becomes instable. Our approach assumes a continues upward flux of material. The result of the simulation is a velocity/diameter relation and hence volume of material at upper outflow with respect to channel width. We find that the velocity of upward migration changes by five orders of magnitude (figure 10a). In contrast to that the volume of mass outflow is almost constant, at least in the same range of magnitude, varying from $10000-30000 \mathrm{~m}^{3} / \mathrm{a}$ (figure $10 \mathrm{~b}$ ). The total amount of conveyed thermal energy, connected to the mass flow is 0.5 $1 * 10^{3} \mathrm{GJ} / \mathrm{a}$ (see figure $10 \mathrm{c}$ ). Looking at the amount of mud, it is remarkablely indifferent to the width of the conduit and should be at least $10000 \mathrm{~m}^{3} / \mathrm{a}$ to deliver a mud of the observed temperature. The controlling factor for this is the heat flux through the mantle surface of the conduit since the material looses $135^{\circ} \mathrm{C}$ of its original temperature or $83 \%$ of its thermal energy on its way up. To consider a conduit as wide as HMMV itself is not necessary in order to maintain a considerable amount of warm mud, a conduit smaller than $1 \mathrm{~m}$ in diameter would result in dramatically increasing velocities (above $12 \mathrm{~km} / \mathrm{a}$ ).

\section{Discussion}

From our temperature measurements we draw three major conclusions: first, the maximum temperature of material near the upper end of the conduit is app. $26^{\circ} \mathrm{C}$, second, very high vertical temperature gradients of $2000-3000 \mathrm{mK} / \mathrm{m}$ only occur near the surface and do not sustain into depth and third, there is a steep horizontal gradient in temperature at a distance of $300-500 \mathrm{~m}$ from the centre.

From this, we divide the observations into two classes, one related to small scale surface effects and the other related to deep seated and long-term effects.

Looking at the small scale effects first, we interpret that we were able to observe a mud flow less than three days old. This corresponds to sea floor observations with "Victor 6000", which show a homogeneous grey mud with absolutely no benthic bioactivity. Evaluating the high resolution bathymetry, this flow covers an area of $5000 \mathrm{~m}^{2}$ while the height is estimated as $3-4 \mathrm{~m}$. The latter value is derived from the bulge-like temperature distribution and additionally from the bathymetric mapping. A calculated mud volume of $15000-$ $20000 \mathrm{~m}^{2}$ is greater or equal to the total annual discharge of HMMV. Thus we can estimate, that a mud flow like the observed one occurs about once a year. The second aspect is the deeper structure of HMMV which was modelled numerically. Two seismic sections (D2-82 and 7200-77 of Hjelstuen) show downward bended reflectors for a horizontal extent of $1-1.5 \mathrm{~km}$ underneath HMMV. Hjelstuen et al. (1999) attribute this effect to a near surface velocity reduction. Horizontal resolution, expressed as the size of the first Fresnel zone can be estimated as $500-700 \mathrm{~m}$. A narrow conduit could not be identified directly but a very large one should. The width of the downward bending effect of seismic horizons is exactly the size of surfacial expression of HMMV. A vertical channel of that size can not be observed further downward, making a very wide conduit unreasonable. 
Looking for a classification of HMMV in comparison to other mud volcano phenomena, we find that HMMV is a mud pie rather than a volcano (Kopf, 2002). From analog modelling it is known that there is a relationship between surface expression and width of the feeder (Lance et al., 1998). Mud pies indicate wide conduits while mud domes result from narrow ones, using the same material. Wide conduits in this case means diameters of some decimetres up to a meter.

The effect of rapid sedimentation can not be neglected at this site. A crustal heat flow related to $33-37 \mathrm{Ma}$ old crust according to Parsons and Sclater (1977) should be $80 \mathrm{~mW} / \mathrm{m}^{2}$. It is convenient to consider the glacial unit only since its sedimentation rate is more than ten times that of the lower preglacial sequence. A mean rate of $1.35 \mathrm{~mm} / \mathrm{a}$ for $2.3 \mathrm{Ma}$ results in a gradient reduction of $55 \%$ according to von Herzen and Uyeda (1963). We actually find values of app. $52-65 \mathrm{~mW} / \mathrm{m}^{2}$ outside the crater of HMMV. This is a bias to higher heat flow than the expected $40 \mathrm{~mW} / \mathrm{m}^{2}$. Either an increased basal heat flow or a heat source within the terrigenous material of the glacial unit can be envisaged for this bias. Thermal conductivity, increased by this magnitude, seems unrealistic.

\section{Summary and conclusion}

Close investigation of the thermal structure of HMMV reveals the dynamic behaviour of this active source of mud, fluid and gas. Narrow spaced temperature measurements allowed to identify an upper temperature limit for outflow of mud. Together with the temperature estimate for the deep seated source of material, this enables a modelling of the amount of mud convection. Having the upper and lower temperatures as known parameters of the conduit, the result is a set of velocity/diameter values. The heat content of the system is balanced by the amount of heat, dissipating through the mantle surface of the conduit. The astonishing result is, that the transported volume is relatively indifferent at a rate of $10000-30000 \mathrm{~m}^{3} / \mathrm{a}$ to changes in diameter for conduits larger than $1 \mathrm{~m}$ in diameter.

The detection of an only 3 days old mud flow is constrained by three features a) its core temperature of app. $26^{\circ} \mathrm{C}$ which can be anticipated as the effluent temperature of the conduit, $b$ ) the very step gradient below the mud line, determined by the mini-lance and c) the virtually unpopulated surface of the area, observed on "Victor 6000" images. A process of successive mud flows can not be attributed for the high temperatures of $20-23^{\circ} \mathrm{C}$ below $10 \mathrm{mbsf}$ because cooling of a singular mud layer would take only 3 months. Thus, mud flows at a frequency of one per year would cool to ambient environment, before superposed by a new one. Our conclusion is that only part of the conveyed heat reaches the surface while a substantial amount of energy and probably material is distributed at the bottom side of the mud pond. Cooling of this "underplated material" is done via conduction through the mantle wall of the pond and by convection of fluids upwards. The upward migration of fluid and gas is expressed in convex shaped gradients, especially between 5 and $10 \mathrm{mbsf}$ and by gas hydrate accumulation within the pond. Furthermore, gas bubbles emerging from HMMV have been observed in significant amounts (Klages et al., 2004, S. 187). 
The thermal situation of HMMV must have been stable for at least thousands of years. The thermal aurora, indicated by the horizontal gradient integrates the source strength with respect to time and temperature. The long term temperature of $\mathrm{HMMV}$ should be between 15 and $30^{\circ} \mathrm{C}$, higher temperatures would yield higher than observed temperatures outside the pond.

\section{Acknowledgements}

Many thanks go to Kapitän Domke of R/V Polarstern and his crew for supplying excellent seamanship during ARK XIX/3b. We are grateful to the Alfred Wegener Institute, namely Michael Klages, Michael Schlüter and Antje Boetius for finance and support of this project. 


\section{References}

Crane, K., E. Sundvor, J.-P. Foucher, M. Hobart, A. M. Myhre, and S. LeDouran, 1988, Thermal Evolution of the Western Svalbard Margin, Marine Geophysical Researches, 9, 165 - 194.

Eldholm, O., E. Sundvor, P. R. Vogt, B. O. Hjelstuen, K. Crane, A. K. Nilsen, and T. P. Gladczenko, 1999, SW Barents Sea continental margin heat flow and Håkon Mosby Volcano, Geo-Marine Letters, 19, 29 - 37.

Fiedler, A., and J. I. Faleide, 1996, Cenocoic sedimentation along the southwestern Barents Sea margin in relation to erosion and uplift of the shelf, Global and Planetary Change, 12, 75 - 93.

Géli, L., J.-L. Turon, D. Aslanian, Y. Balut, P. Beuzart, J. Cochran, J. Francheteau, F. Harmegnies, J.-Y. Landuré, et al., 2001, Deeppenetration heat flow probes raise questions about interpretation from shorter probes, EOS, 82, 317-320.

Ginsburg, G. D., A. V. Milkov, A. V. Soloviev, A. V. Egorov, G. A. Cherkashev, P. R. Vogt, K. Crane, T. D. Lorenson, and M. D. Khutorskoy, 1999, Gas hydrate accumulation at the Håkon Mosby Mud Volcano, Geo-Marine Letters, 19, 57 - 67,.

Henry, P., X. LePichon, S. Lallemant, S. Lance, J. B. Martin, J. P. Foucher, A. Fiala-Médioni, F. Rostek, N. Guilhaumou, et al., 1996, Fluid flow in and around a mud volcano field seaward of the Barbados accretionary wedge: results from Manon cruise, J. Geophys. Res., 101, 20297-20323.

Von Herzen, R. P., 1963, Geothermal heat flow in the Gulfs of California and Aden, Science, 140, 1207-1208.

Hjelstuen, B. O., O. Eldholm, J. I. Faleide, and P. R. Vogt, 1999, Regional setting of Håkon Mosby Mud Volcano, SW Barents Sea margin, GeoMarine Letters, 19, 22 - 28.

Hyndman, R. D., E. E. Davis, and J. A. Wright, 1979, The measurement of marine geothermal heat flow by a multipenetration probe with digital acoustic telemetry and in situ thermal conductivity, Mar. Geophys. Res., 4, $181-205$.

Klages, M., Thiede, J. and Foucher, J.-P., 2004, The Expeditions ARK XIX 3a, $3 \mathrm{~b}$ and $3 \mathrm{c}$, Berichte zur Polarforschung, 488.

Kopf, A. J., 2002, Significance of mud volcanism, Reviews of Geophysics, 40.

Kopf, A. J., and J. H. Behrman, 2000, Extrusion dynamics of mud volcanoes on the Mediterranean Ridge accretionary complex, in: From the Arctic to the Mediterranean: salt, shale, and igneous diapirs in and around Europe, edited by B. Venderville, Y. Mart, and J.-L. Vigneresse, pp 169-204, Geol. Soc. London, London. 
Lance, S., P. Henry, X. Le Pichon, S. Lallemant, H. Chamley, F. Rostek, J.-C. Faugeres, E. Gonthier, and K. Olu, 1998, Submersible study of mud volcanoes seaward of Barbados accretionary wedge: Sedimentology, structure and rheology, Marine Geology, 145, 255 - 292.

Müller, R. D., 1997, Digital isochrons of the world's ocean floor, J. Geophs. Res., 102, 3211.

National Geophysical Data Center, 2004, Global Digital Elevation Model (ETOPO2), ESRI, Redlands, California, USA.

Parsons, B., and J. G. Sclater, 1977, An analysis of the variation of ocean floor bathymetry and heat flow with age, J. Geophys. Res., 32, $803-827$.

Schmidt, M., C. Hensen, T. Mörz, C. Müller, I. Grevemeyer, K. Wallmann, S. Mau, and N. Kaul, 2005, Methane hydrate accumulation in "Mound 11" mud volcano, Costa Rica forearc, Marine Geology, 216, 77-94.

Sundvor, E., Eldholm, O., Gladczenko, T.P., and Planke, S., 2000, NorwegianGreenland sea thermal field. Geol. Soc. London Spec. Publ., 167, 397410.

Vogt, P. R., G. Cherkashev, G. Ginsburg, G. Ivanov, A. Milkov, K. Crane, A. Lein, E. Sundvor, N. Pimenov, and A. Egorov, 1997, Håkon Mosby Mud Volcano provides unusual example of venting, EOS, Transactions, AGU, $78,549-557$, . 
Table 1: Interpolated temperatures at relative depths with respect to the uppermost

sensor. Conductivity values $\mathrm{k}^{\star}$ are calculated from measurements, others are

spatially interpolated.

\begin{tabular}{|c|c|c|c|c|c|c|c|c|c|c|}
\hline & Lon & Lat & HF-Name & $\mathrm{k}$ & T_0m & T_1m & T_2m & T_3m & $\begin{array}{l}\text { Gradient } \\
{[\mathrm{mK} / \mathrm{m}]}\end{array}$ & PS64/station \\
\hline 1 & 14.7064 & 72.0136 & H0310P01 & $1.11^{*}$ & -0.76 & -0.7 & -0.63 & -0.56 & 67 & PS64/319-1 \\
\hline 2 & 14.7115 & 72.0114 & H0310Р02 & 1.11 & -0.75 & -0.69 & -0.52 & -0.56 & 66 & PS64/319-2 \\
\hline 3 & 14.7167 & 72.0092 & Н0310Р03 & 1.11 & -0.69 & -0.6 & -0.52 & -0.41 & 86 & PS64/319-3 \\
\hline 4 & 14.7201 & 72.0078 & H0310Р04 & $1.40 *$ & -0.48 & -0.31 & -0.05 & 0.15 & 240 & PS64/319-4 \\
\hline 5 & 14.7235 & 72.0063 & H0310P05 & $1.08^{*}$ & -0.5 & 2 & 3.5 & 5.0 & 2740 & PS64/319-5 \\
\hline 6 & 14.7252 & 72.0056 & H0310Р06 & 1.08 & 5 & 5.5 & 8 & 10.5 & 2430 & PS64/319-6 \\
\hline 7 & 14.727 & 72.0049 & H0310Р07 & 1.08 & 24.5 & 26.0 & 25.4 & 25.2 & -98 & PS64/319-7 \\
\hline 8 & 14.7287 & 72.0042 & H0310Р08 & $1.02 *$ & 11.5 & 12 & 14.5 & 17 & 2500 & PS64/319-8 \\
\hline 9 & 14.7304 & 72.0034 & H0310P09 & $1.00 *$ & 4.5 & 6.5 & 8.4 & 10.5 & 2050 & PS64/319-9 \\
\hline 10 & 14.7321 & 72.0027 & H0310P10 & $0.96 *$ & 7 & 9 & 11 & 13.3 & 2010 & PS64/319-10 \\
\hline 11 & 14.7355 & 72.0012 & H0310P11 & $1.27^{*}$ & -0.68 & -0.59 & -0.5 & -0.41 & 90 & PS64/319-11 \\
\hline 12 & 14.7406 & 71.9991 & H0310P12 & $1.19 *$ & -0.78 & -0.71 & -0.64 & -0.62 & 70 & PS64/319-12 \\
\hline 13 & 14.7458 & 71.9969 & H0310P13 & $1.13^{*}$ & -0.8 & -0.74 & -0.67 & -0.61 & 62 & PS64/319-13 \\
\hline 14 & 14.7492 & 71.9954 & H0310P14 & $1.11 *$ & -0.8 & -0.74 & -0.68 & -0.62 & 61 & PS64/319-14 \\
\hline 15 & 14.7528 & 71.9933 & H0310P15 & $1.12 *$ & -0.8 & -0.74 & -0.68 & -0.62 & 60 & PS64/319-15 \\
\hline 16 & 14.7615 & 71.9893 & H0310P16 & $1.12 *$ & -0.81 & -0.75 & -0.69 & -0.64 & 57 & PS64/319-16 \\
\hline 17 & 14.7112 & 72.0042 & H0311P01 & 1.00 & -0.8 & -0.58 & -0.42 & -0.27 & 153 & PS64/333-1 \\
\hline 18 & 14.7141 & 72.0042 & H0311P02 & $1.03^{*}$ & -0.51 & -0.1 & 0.3 & 0.8 & 433 & PS64/333-2 \\
\hline 19 & 14.717 & 72.0042 & H0311P03 & $1.12 *$ & 0.5 & 1.4 & 2.3 & 3.1 & 936 & PS64/333-3 \\
\hline 20 & 14.7199 & 72.0042 & H0311P04 & $1.18^{*}$ & 1.2 & 2.8 & 4.5 & 6.2 & 1760 & PS64/333-4 \\
\hline 21 & 14.7228 & 72.0042 & H0311P05 & 1.00 & 23 & 23.8 & 24.2 & 24.6 & 402 & PS64/333-5 \\
\hline 22 & 14.7257 & 72.0042 & H0311P06 & 1.00 & 16 & 18 & 20 & 22.5 & 2000 & 4/333-6 \\
\hline 23 & 14.7288 & 72.0042 & H0311P07 & 1.00 & 13.6 & 13.8 & 14.1 & 14.4 & 325 & PS64/333-7 \\
\hline 24 & 14.7316 & 72.0042 & H0311P08 & $0.69 *$ & 10.1 & 11.8 & 13.4 & 15 & 1590 & PS64/333-8 \\
\hline 25 & 14.7345 & 72.0042 & H0311P09 & 1.00 & 8.9 & 10 & 11 & 12 & 1070 & PS64/333-9 \\
\hline 26 & 14.7374 & 72.0042 & H0311P10 & $1.15^{*}$ & -0.2 & 0.3 & 0.9 & 1.5 & 564 & PS64/333-10 \\
\hline 27 & 14.7403 & 72.0042 & H0311P11 & 1.00 & -0.6 & -0.45 & -0.3 & -0.17 & 138 & PS64/333-11 \\
\hline 28 & 14.7432 & 72.0042 & H0311P12 & $1.34 *$ & -0.72 & -0.64 & -0.56 & -0.5 & 72 & PS64/333-12 \\
\hline 29 & 14.7461 & 72.0042 & H0311P13 & $1.16^{*}$ & -0.75 & -0.68 & -0.6 & -0.56 & 75 & PS64/333-13 \\
\hline 30 & 14.7287 & 72.0087 & H031 & $1.16^{*}$ & -0.5 & -0.3 & -0.06 & 0.15 & 229 & 333-14 \\
\hline 31 & 14.7287 & 72.0078 & H0312P02 & $1.11 *$ & -0.2 & 0.5 & 1.2 & 1.9 & 708 & PS64/333-15 \\
\hline 32 & 14.7287 & 72.0069 & Н0312Р03 & $1.22 *$ & -0.8 & -0.2 & 0.3 & 1.0 & ? & PS64/333-16 \\
\hline 33 & 14.7287 & 72.006 & H0312P04 & $1.7^{*}$ & -0.8 & -0.6 & 0.2 & 0.9 & 834 & PS64/333-17 \\
\hline 34 & 14.7287 & 72.0051 & H0312P05 & $0.73^{*}$ & 4.5 & 6.2 & 8.3 & 10.1 & 1990 & PS64/333-18 \\
\hline 35 & 14.7287 & 72.0043 & H0312P06 & $1.19 *$ & 2.5 & 4.4 & 6.2 & 8 & 1870 & PS64/333-19 \\
\hline 36 & 14.7287 & 72.0033 & H0312P07 & 1.10 & 10 & 12 & 14.2 & 16.5 & 2140 & PS64/333-20 \\
\hline 37 & 14.7287 & 72.0024 & H0312P08 & $0.99 *$ & 4 & 6 & 8 & 10 & 2090 & PS64/333-21 \\
\hline 38 & 14.7287 & 72.0015 & H0312P09 & $1.13^{*}$ & 5 & 7 & 8.6 & 10.8 & 1910 & PS64/333-22 \\
\hline 39 & 14.7287 & 72.0006 & H0312P10 & $1.11^{*}$ & -0.5 & -0.2 & 0.1 & 0.39 & 275 & PS64/333-23 \\
\hline 40 & 14.7217 & 72.02 & $\mathrm{H} 03$ & 1.1 & -0.79 & -0.73 & -0.68 & -0.62 & 5 & \\
\hline 41 & 14.7216 & 72.0237 & H0313Р02 & 1.1 & -0.78 & -0.73 & -0.67 & -0.62 & 55 & PS64/343-2 \\
\hline 42 & 14.7215 & 72.0219 & Н0313Р03 & $1.09 *$ & -0.78 & -0.73 & -0.66 & -0.61 & 58 & PS64/343-3 \\
\hline 43 & 14.7213 & 72.0201 & H0313Р04 & 1.1 & -0.77 & -0.72 & -0.66 & -0.6 & 59 & PS64/343-4 \\
\hline 44 & 14.7212 & 72.0183 & H0313Р05 & $1.09 *$ & -0.78 & -0.72 & -0.66 & -0.6 & 59 & PS64/343-5 \\
\hline 45 & 14.7211 & 72.0165 & H0313Р06 & 1.1 & -0.77 & -0.72 & -0.65 & -0.59 & 61 & PS64/343-6 \\
\hline 46 & 14.721 & 72.0147 & H0313Р07 & $1.13^{*}$ & -0.75 & -0.69 & -0.62 & -0.55 & 66 & PS64/343-7 \\
\hline 47 & 14.721 & 72.0129 & H0313Р08 & $1.15^{*}$ & -0.72 & -0.65 & -0.59 & -0.51 & 71 & PS64/343-8 \\
\hline 48 & 14.7209 & 72.0111 & H0313Р09 & 1.1 & -0.7 & -0.63 & -0.56 & -0.49 & 73 & PS64/343-9 \\
\hline 49 & 14.7208 & 72.0093 & H0313P10 & 1.1 & -0.65 & -0.57 & -0.48 & -0.39 & 89 & PS64/343-10 \\
\hline
\end{tabular}




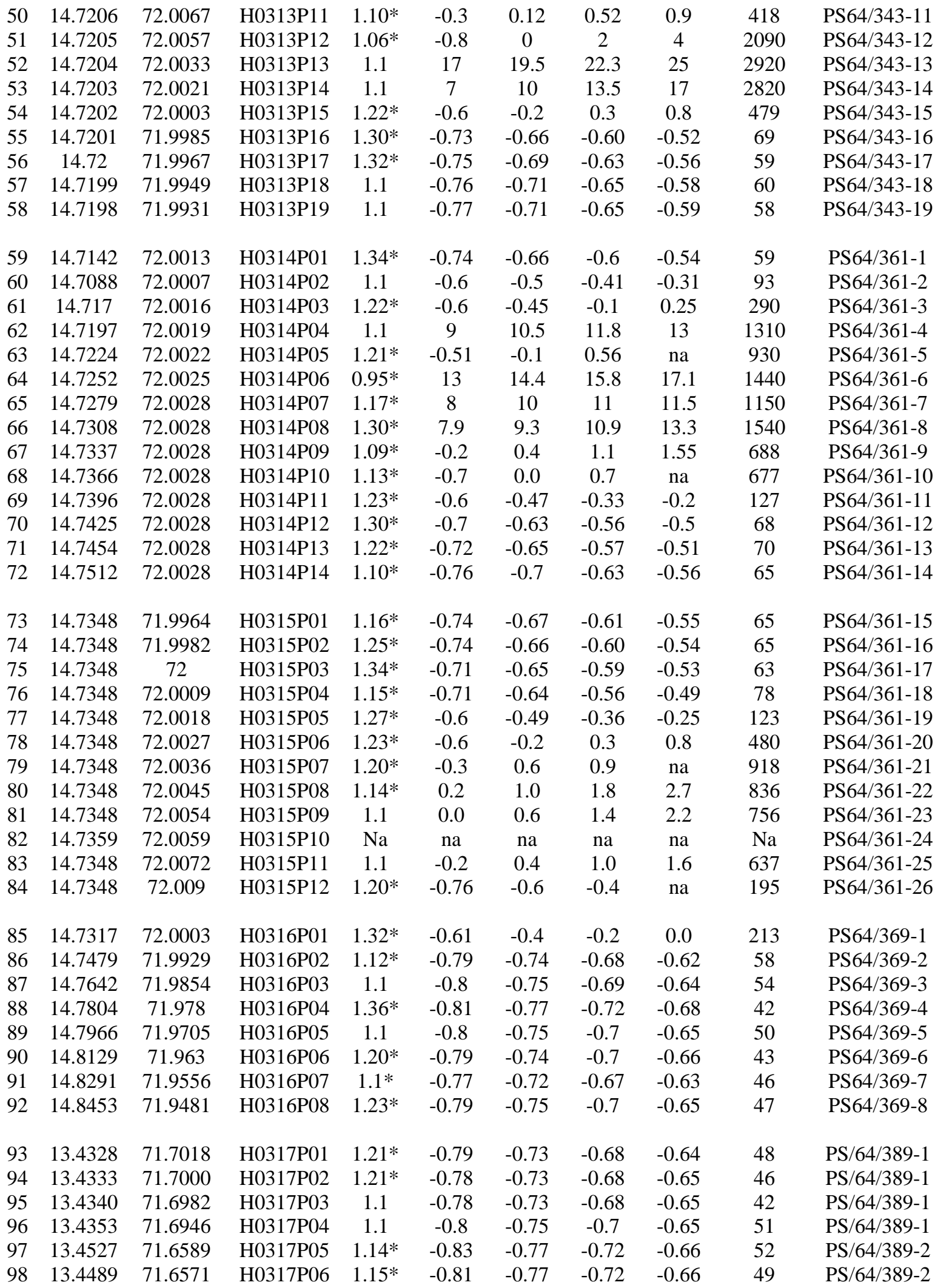




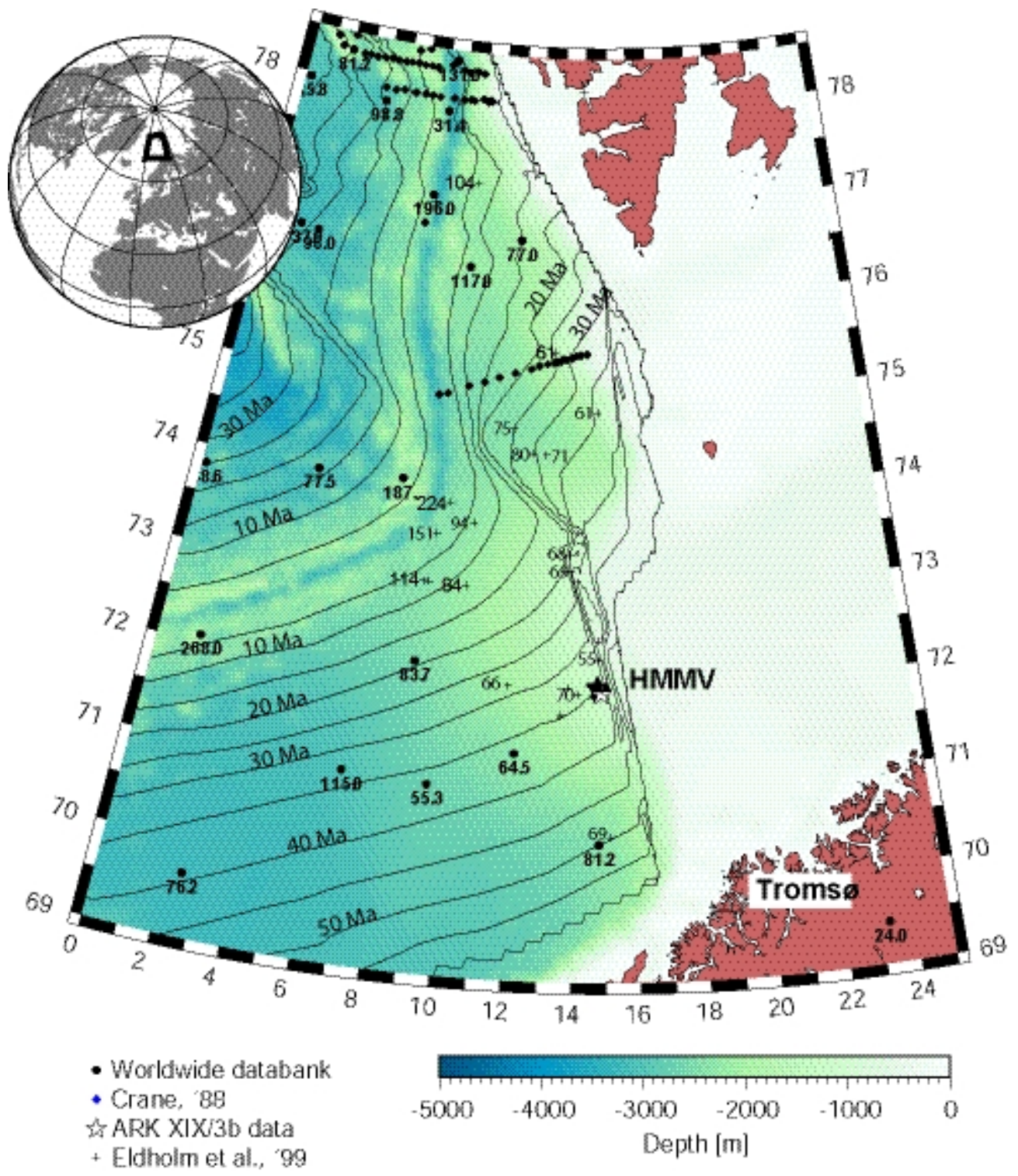

Figure 1: Working area in the Southwest Barents Sea and regional heat flow determinations. Håkon Mosby mud volcano (HMMV) is situated at a scarp on the flank of the Barents-Svalbard continental margin. Bathymetry data from ETOPO2 (NGDC, 2004) dataset allows to identify this depression. Age of oceanic crust is taken from Müller (1997). HMMV area is closely sampled with temperature measurements. 


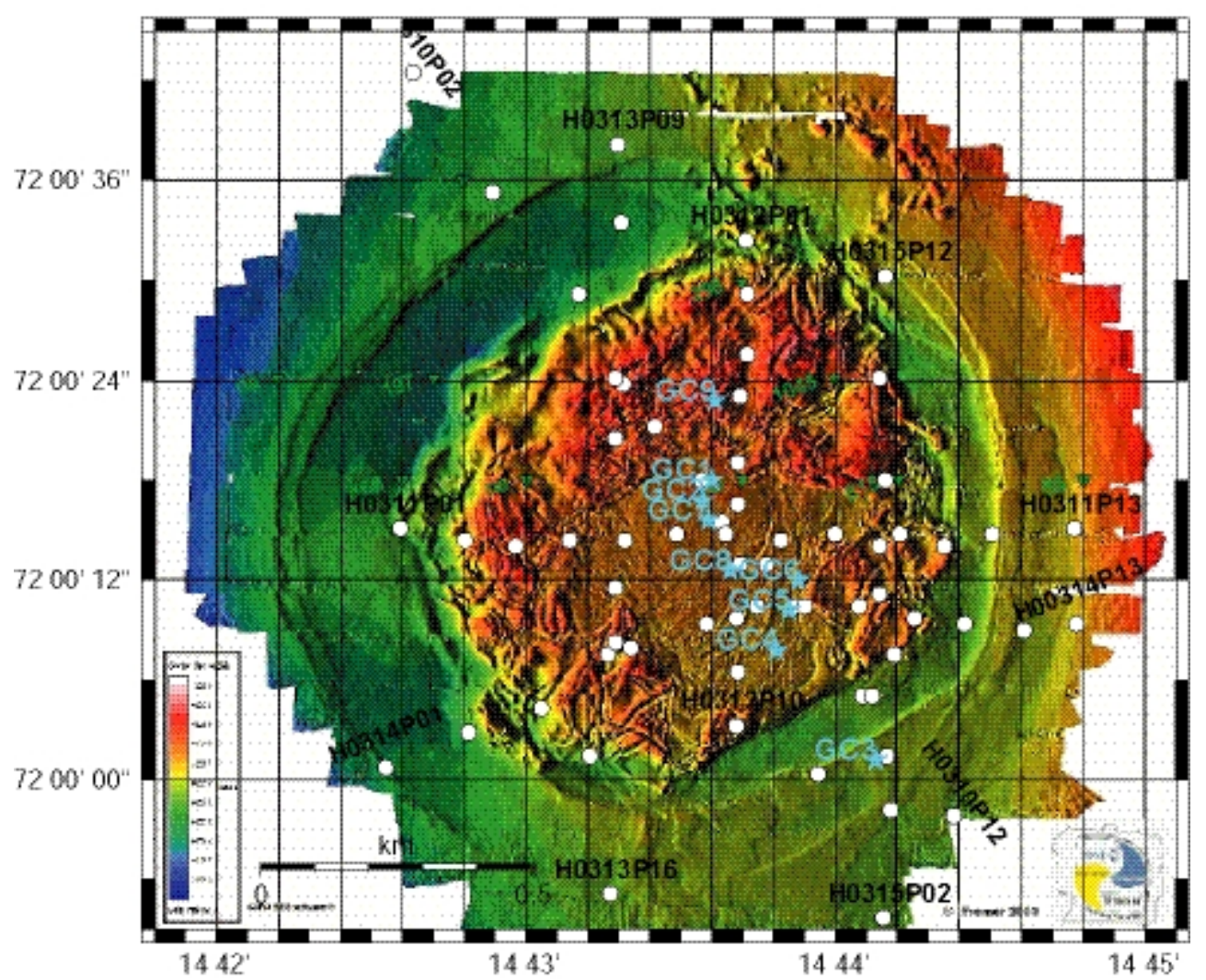

Figure 2: High resolution bathymetry of Håkon Mosby mud volcano, produced by IFREMER, using deep towed multi-beam echosounders, mounted beneath ROV "Victor 6000". Overlain are positions of heat flow positions (white dots) and gravity corers (blue stars). A zonation is i): outside the moat, ii) the moat ring, iii) a rough area north and west of the centre and iv) a smooth area expanding from the centre southwards. 


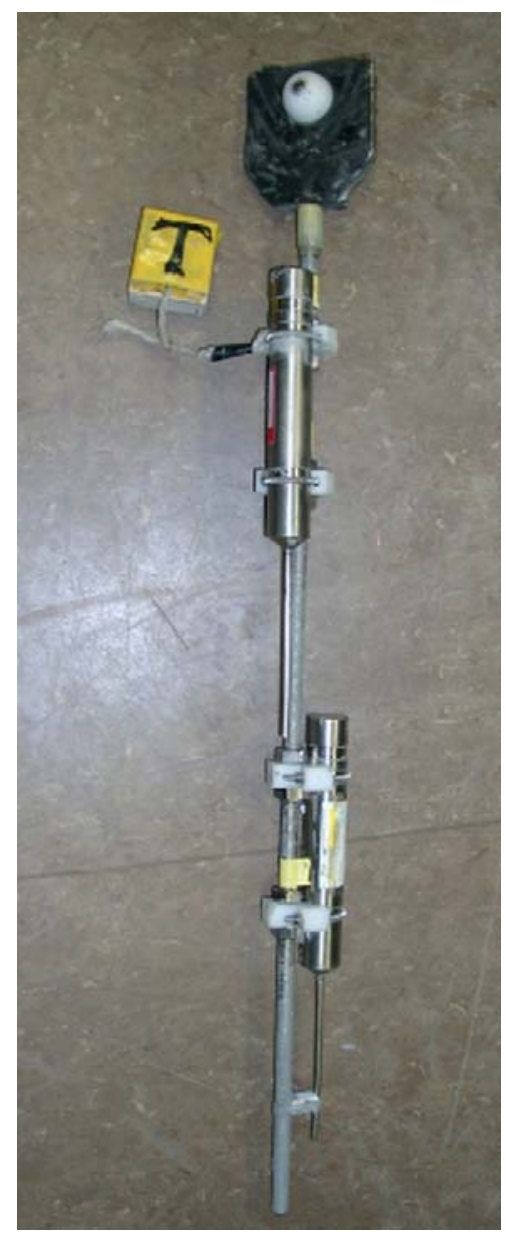

Figure 3: Mini temperature lance equipped with two MICREL temperature sensors. 

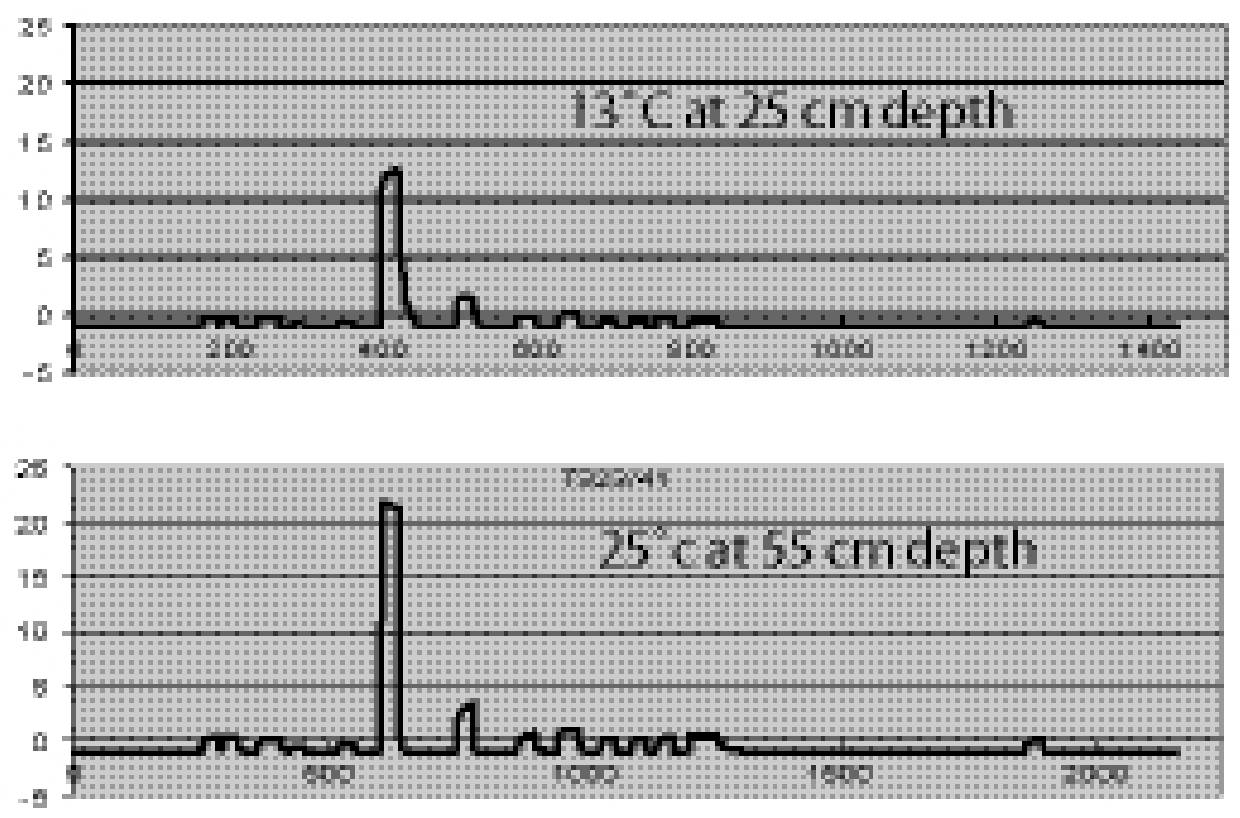

Figure 4: Temperature measurements as time series of the two MICREL sensors, mounted onto a mini lance. Sensor positions are 55 and $25 \mathrm{~cm}$ below the top of the lance. The position of the maximum temperature coincides with the highest temperatures found with the Bremen heat probe. 

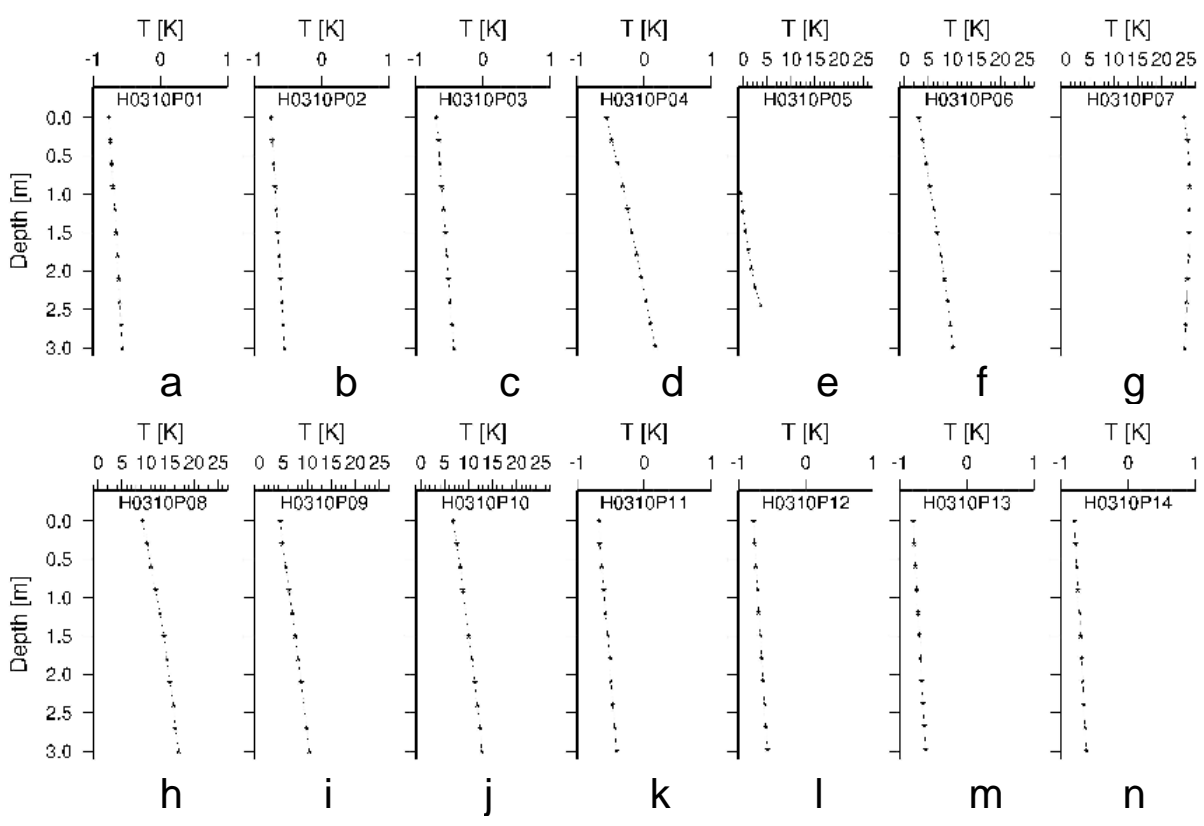

Figure 5: Temperature-depth plots of station H0310, aligned in a NW-SE direction across the centre of HMMV. Temperature scales of figures $\mathrm{e}-\mathrm{j}$ are compressed by a factor of 13 to accommodate for the higher temperatures within the central crater. At the very centre (H0310P07, g), high temperatures correlate with a low gradient. 


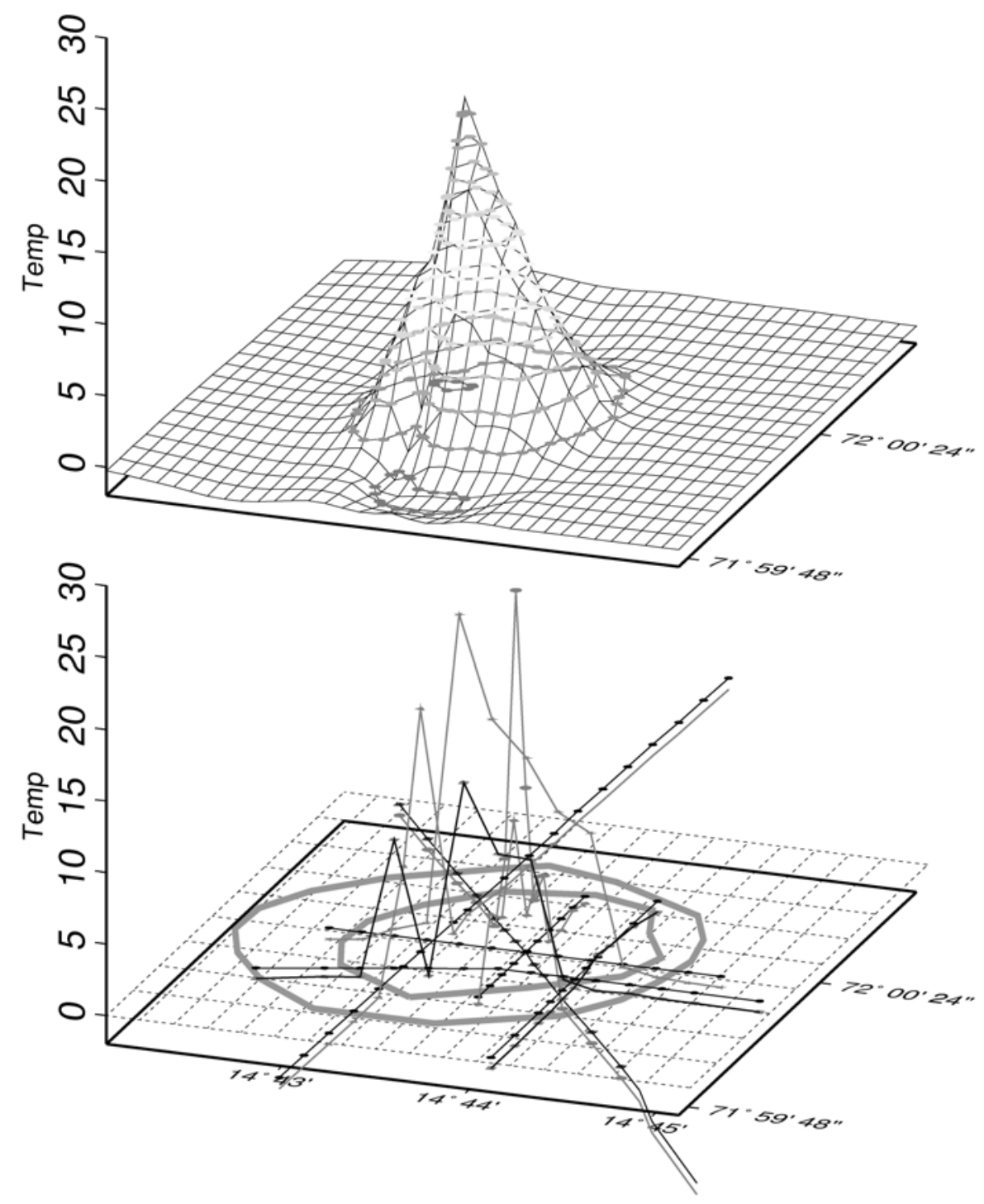

Figure 6) Compilation of temperature data of the uppermost sensor of all locations near HMMV. The upper part shows a smoothed version of the dataset while the lower part displays the irregular distributed data points and their projections onto the base lines. Concentric circles indicate the position of inner and outer rim of HMMV. 


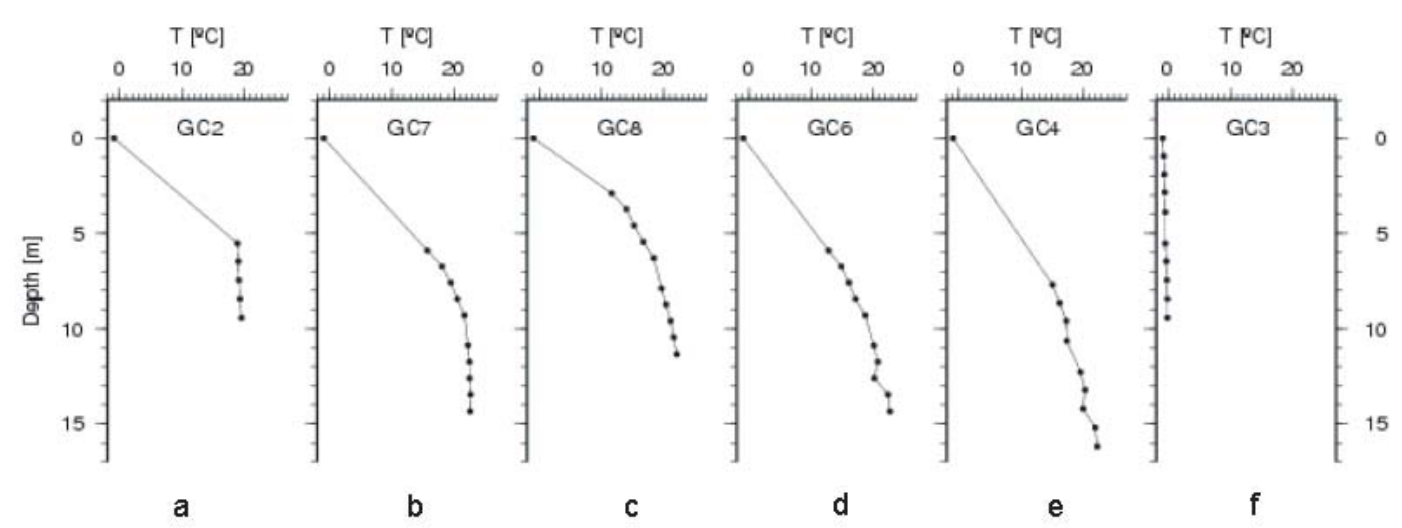

Figure 7) Data from 6 successful gravity corers. a) GC 2 located near the centre, b) c) between centre and moat rim and f) outside the moat rim. Temperature scale is identical $0-25^{\circ} \mathrm{C}$. 


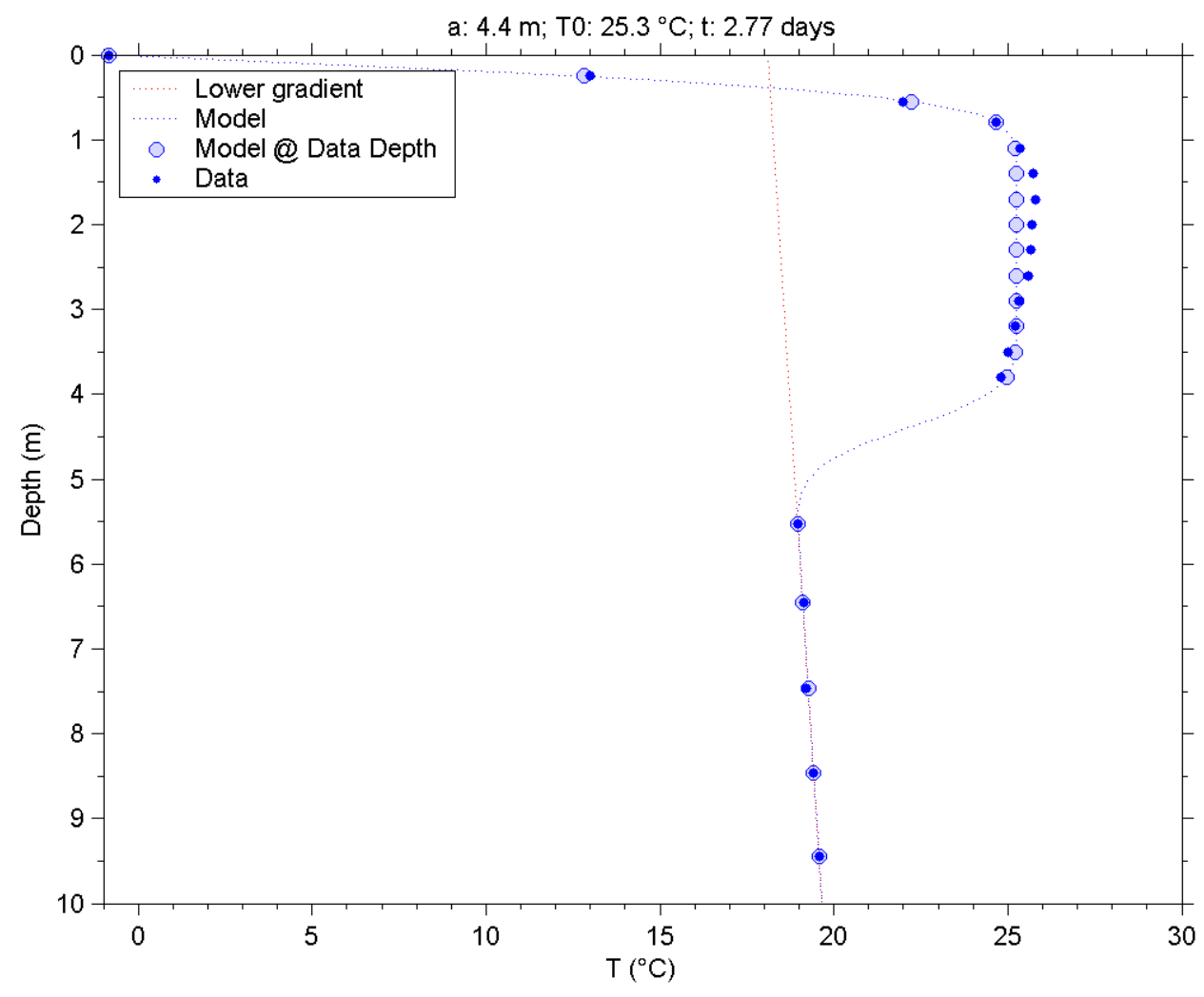

Figure 8) A composite temperature profile from $0-10 \mathrm{mbsf}$. Small dots are data points, larger dots represent temperatures, modelled for one mud flow of $4 \mathrm{~m}$ thickness, extruded 3 days before at a temperature of $26^{\circ} \mathrm{C}$. 


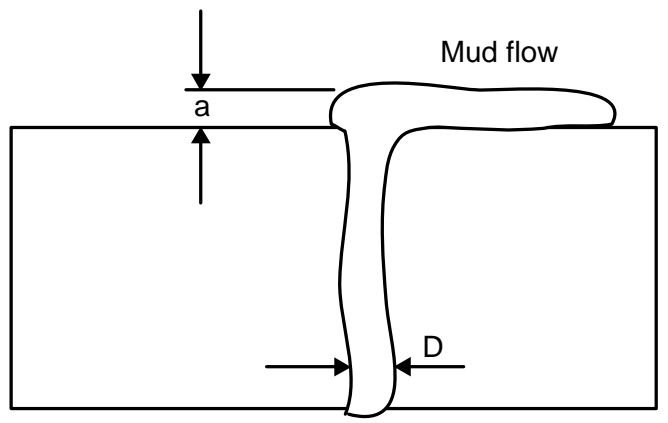

Figure 9) Model parameters for a singular mud flow. 


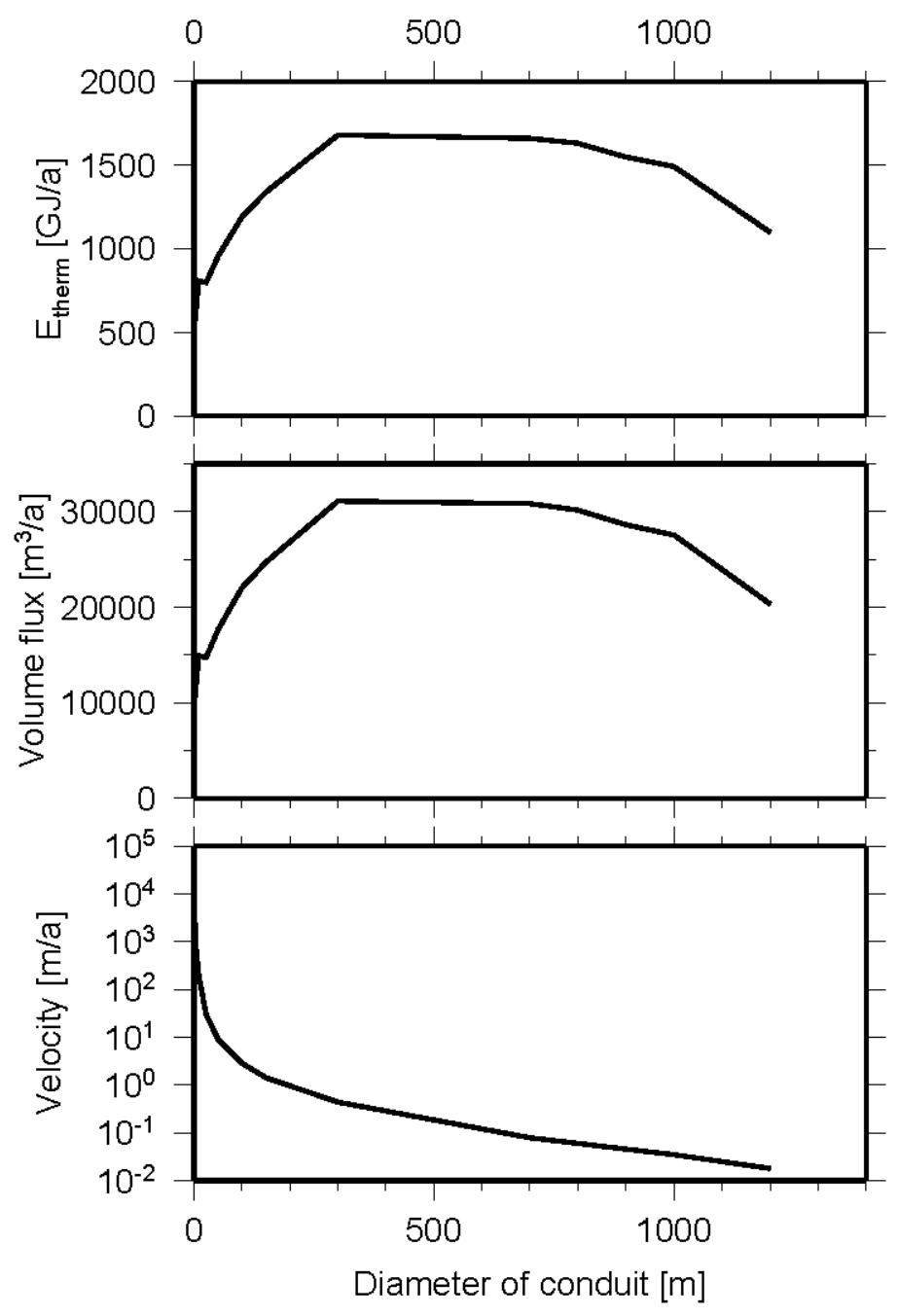

Figure 10) Results of modelling rates of mud expulsion with respect to conduit diameter. Lower: migration velocity vs. conduit diameter. Boundary conditions are temperatures at lower and upper end of conduit. Middle: Mud volume expulsion does not exceed certain limits. Upper: thermal energy, transported with the expulsed mud corresponds to the amount of mud. 